\title{
QUALITY OF LIFE OF PATIENTS WITH OBSTRUCTIVE SLEEP APNEA SYNDROME TREATED WITH AN INTRAORAL MANDIBULAR REPOSITIONER
}

\author{
Marco Antonio Cardoso Machadoㄹ, Lucila Bizari Fernandes do Prado², \\ Luciane Bizari Coin de Carvalho3, Silvio Francisco4, Ademir Baptista da Silva5, \\ Álvaro Nagib Atallah6, Gilmar Fernandes do Prado ${ }^{7}$
}

\begin{abstract}
Background: Obstructive sleep apnea syndrome (OSAS) is a very important and prevalent disease, which is associated with a poor quality of life in many patients. Treatments for OSAS include surgery, Continuos Positive Air way Pressure, and an intraoral mandibular repositioner (IOMR), but the tendency of sleep centers is to emphasize the apnea index, neglecting quality of life as treatment outcome. Objective: To verify to what extent treatment with an IOM R improves the OSAS patient's quality of life. Method: Eleven male patients aged 34 to 63 years (mean $=49$ ) with mild to moderate OSAS were evaluated using the Calgary SAQLI questionnaire applied before and four weeks after treatment with an IOMR. The mandibular repositioners were manufactured individually for each patient with acrylic polymer and equipped with a retentive device to maintain the mandible in a forward position during sleep. Results: Excellent improvement in the quality of life was observed in five patients (45.5\%) and excellent improvement in symptoms in $10(90.9 \%)$. Conclusion: The systematic use of the IOMR indicates a clear improvement in the global quality of life as well as in the symptoms of patients with OSAS.
\end{abstract}

KEY WORDS: obstructive sleep apnea syndrome, intraoral mandibular repositioner, and quality of life.

\begin{abstract}
Qualidade de vida em pacientes com síndrome de apnéia obstrutiva do sono tratados com reposicionador mandibular intra-oral

RESUM 0 - Contexto. A síndrome da apnéia obstrutiva do sono (SAOS) é importante e prevalente doença associada à má qualidade de vida em muitos pacientes. Os tratamentos disponíveis incluem cirurgias, CPAP e 0 aparelho reposicionador mandibular intraoral (ARM IO). Muitos centros de distúrbios de sono valorizam apenas a redução do número de apnéias no tratamento da SAOS, dando pouca atenção à qualidade de vida como desfecho do tratamento. Objetivo: Graduar melhora da qualidade de vida dos pacientes com SAOS usando ARM IO. Método: 0 questionário Calgary SAQ LI foi aplicado, antes e após, 4 semanas de tratamento com ARM IO, a 11 pacientes masculinos, entre 34 e 63 anos de idade (média de 49 anos), com SAOS leve a moderada. ARM IOs foram manufaturados com polímero acrílico e providos com retentivos para manter a mandíbula em posição anterior durante 0 sono. Resultados: Observamos grande melhora na qualidade de vida em 5 pacientes (45,5\%) e melhora dos sintomas em $10(90,9 \%)$. Conclusão: 0 uso do ARMIO associa-se principalmente à melhora dos sintomas, como também à melhora da qualidade de vida global.
\end{abstract}

PALAVRAS-CHAVE: síndrome da apnéia obstrutiva do sono, aparelho reposicionador mandibular intra-oral, qualidade de vida.

The quality of life of modern humans is dependent on socioeconomic, cultural and health factors. Disease, in addition to affecting the psychological and emotional state of the individual, compromises family income, causing damage to education, housing and social interaction ${ }^{1,2}$. Obstructive sleep apnea syndrome (OSAS) is characterized by complete or partial obstruction of the upper airways during sleep, mainly at the level of the oropharynx, with repeated and prolonged pauses of respiration and oxyhemoglobin desaturation followed by arousal and resumption of respiration ${ }^{3,4}$. OSAS is

Center for Clinic and Science of Sleep (CCSS), Departments of Neurology and Emergency M edicine, Federal University of São Paulo, São Paulo SP, Brazil: 1DDS, CCSS, Departments of Neurology and Emergency Medicine; ${ }^{2} \mathrm{MD}$, Co-Director of CCSS, Departments of Neurology and Emergency Medicine; ${ }^{3 P h D}$, CCSS, Departments of Neurology and Emergency M edicine; ${ }^{4} \mathrm{MD}$, CCSS, Departments of Neurology and Emergency M edicine; ${ }^{5} \mathrm{MD}$, PhD, Department of Neurology; ${ }^{6} \mathrm{MD}$, PhD, Department of Emergency M edicine; ${ }^{7}$ M D,PhD, Director of CCSS, Departments of Neurology and Emergency Medicine.

Received 1 A pril 2003, received in final form 16 October 2003. Accepted 28 November 2003.

Dr. Gilmar F. Prado - Rua Claudio Rossi 394 -01547-000 São Paulo SP - Brasil. E-mail: gilmar.dmed@epm.br 
associated with an increase in adipose tissue in the oropharynx, tonsil hypertrophy, macroglossia and structural anomalies such as stenosis of the oropharynx and retrognathia. Diurnal symptoms of the disease include hypersomnia and memory and attention impairment. OSAS has been suggested to cause acute myocardial infarction, cerebral vascular accident and heart failure, among others ${ }^{4}$. Patients with OSAS seeking medical care report unwillingness to carry out daily tasks, irritability in response to small difficulties and lack of sexual interest. The report of the spouse, who in most cases accompanies the patient, almost always consists of complaints about loud snoring and respiratory arrest followed by sudden and agonizing arousals. Many patients with OSAS are not aware of what is happening during sleep, reporting only tiredness and daytime hypersomnia. The report of the bedroom companion, together with clinical signs and symptoms, leads to the diagnostic suspicion of OSAS which is confirmed by polysomnography ${ }^{4,5}$.

OSAS disorganizes the relational life of the patient, affecting his/her ability to maintain an adequate social life and negatively influencing his/her quality of life ${ }^{1}$. Intraoral devices have been developed as an alternative treatment for OSAS, and some studies have shown improvement in the quality of life of patients who systematically use an intraoral device that positions the mandible anteriorly and increases the dimensions of the collapsible region of the airways ${ }^{6-8}$. In addition to the cited mandibular repositioners, other treatments available include continuous positive airway pressure (CPAP) - the standard treatment for severe apneas - and surgical procedures which, how ever, have not yet been evaluated in high quality clinical studies $^{9,10}$. Intraoral mandibular repositioners (IOMR) have been playing an important role in the treatment of patients with mild to moderate OSAS, i.e., an apnea-hypopnea index (AHI) of up to 30 events per hour of sleep ${ }^{4,11-13}$. In this respect, a correct indication of these appliances can result in great benefit to the patient, reestablishing his/her health in a less aggressive manner, with low costs and without the complications inherent to surgical procedures. Therefore, we carried out the present study to determine the effect of a mandibular repositioner on the quality of life of patients with OSAS ${ }^{14}$.
Eleven male patients with OSAS ranging in age from 34 to 63 years (mean: 49 years), with a medical indication for the use of a mandibular repositioner based on a previous polysomnographic study that showed an $\mathrm{AHI}$ below 30 events per hour, participated in the study.

We used the Calgary Sleep Apnea Quality of Life Index (Calgary SAQLI) - a disease-specific quality of life questionnaire - in which all items influencing the quality of life of patients with OSAS w ere identified $^{15,16}$. The Calgary SAQLI contains 35 questions organized in such a way as to permit the assessment of five functional domains, i.e., daily routine, social interactions, emotional state, symptoms, and side effects, in order to determine the possible negative influence of treatment.

The Calgary SAQLI was applied to each patient on his/her first visit to the dental office. Once the device was manufactured and installed, the patient was instructed to use the mandibular repositioner for 4 weeks and the questionnaire was then reapplied.

The IOMR were manufactured using dental self-polymerizing acrylic resin, and consisted of a resin plate for occlusal covering of the upper arch and another occlusal plate for covering of the lower arch. The plates were fitted with retentive clasps to guarantee fixation and stabilization of the mandible. The plates were connected by a stainless steel mechanism that permitted advancement of the lower plate in relation to the upper plate in tens of millimeters.

After molding, manufacturing and installation of the device, the patients were kept under weekly observation for 4 weeks, receiving weekly assessment and adjustments, and the Calgary SAQLI questionnaire was again applied at the end of this period. In an additional fifth session, the possible negative impacts of treatment on the quality of life of each patient were determined.

\section{Data analysis and interpretation}

The Calgary SAQLI provides two groups of values: one associated with pretreatment and the other with post-treatment, with the difference between them (important minimum difference $=I M D$ ) being considered for evaluation of the procedure. As standardized, an IMD of 1.0 in the Calgary SAQLI questionnaire indicates improvement in the quality of life ${ }^{15}$. A general IMD and an IMD for each domain were then calculated. Improvement was scored as small (1.00 to 1.49), good (1.50 to 1.99) and excellent (above 2.00).

\section{METHOD}

\section{RESULTS}

Table 1. Percent improvement in the quality of life of patients with obstructive sleep apnea syndrome treated with an intraoral mandibular repositioner as determined by the Calgary SAQLI questionnaire.

\begin{tabular}{lccccc}
\hline Improvement & $\begin{array}{c}\text { Global } \\
\text { result }\end{array}$ & $\begin{array}{c}\text { Daily } \\
\text { routine }\end{array}$ & $\begin{array}{c}\text { Social } \\
\text { interactions }\end{array}$ & $\begin{array}{c}\text { Emotional } \\
\text { state }\end{array}$ & Symptoms \\
\hline Absent & 0 & 0 & $1(9.1 \%)$ & $3(27.2 \%)$ & 0 \\
Small & $4(36.3 \%)$ & $2(18.2 \%)$ & $3(27.2 \%)$ & $3(27.2 \%)$ & 0 \\
Good & $2(18.2 \%)$ & $5(45.5 \%)$ & $3(27.2 \%)$ & $2(18.2 \%)$ & $3(18.2 \%)$ \\
Excellent & $5(45.5 \%)$ & $4(36.3 \%)$ & $4(36.3 \%)$ & $3(27.2 \%)$ & $8(79.8 \%)$ \\
\hline
\end{tabular}


According to the concept of the IMD, all patients of the present study treated with the mandibular repositioner showed small to excellent improvement according to our classification when assessed by the Calgary SAQLI questionnaire. As shown in Table 1, $4(36.3 \%)$ of the 11 participants showed small improvement, 2 (18.2\%) good improvement, and 5 (45.5\%) excellent improvement, with none of the patients showing lack of improvement.

Improvement was also observed for the daily routine domain, with $4(36.3 \%)$ patients showing excellent improvement, 5 (45.5\%) good improvement and 2 (18.2\%) small improvement. More than $80 \%$ of the patients reached good to excellent improvement, with none of the patients showing lack of improvement in this domain.

With respect to social interactions, 4 patients $(36.5 \%)$ showed excellent improvement, 3 (27.2\%) good improvement, and $3(27.2 \%)$ small improvement, while one patient $(9.1 \%)$ did not present any improvement.

Regarding emotional state, 3 (27.2\%) patients showed excellent improvement, 2 (18.2\%) good improvement, and 3 $(27.2 \%)$ small improvement, while no improvement in emotional state was observed for 3 other patients.

The symptom domain yielded the most surprising results and was probably the factor mainly responsible for the improved quality of life observed for all patients treated with the mandibular repositioner in the present study. Excellent improvement was reached by $8(79.8 \%)$ patients and good improvement by $3(18.2 \%)$ patients.

No side effects were reported by the patients using the IOM R throughout the study period.

\section{DISCUSSION}

All patients of the present study showed some degree of improvement in their quality of life upon global assessment. Only 3 patients did not show improvement in specific domains such as emotional state or social interaction, despite improvement in the global score. These patients probably presented other parallel clinical conditions contributing to OSAS such as depression, anxiety, insomnia and periodic limb movement syndrome, which were not the subject of the present investigation ${ }^{4}$. With respect to the symptom domain, the excellent improvement observed for this group of patients might have been due to the marked reduction in the $\mathrm{AHI}$ as a result of the use of the IOMR ${ }^{10}$.

There is no doubt that OSAS is associated with clinical, psychological and social alterations, causing deterioration of the health of patients in a subtle but incisive and long-lasting manner, with the disorder not being easily detected. In this respect, the Calgary SAQLI questionnaire has been shown to be an excellent instrument for the determination of the quality of life of patients with OSAS ${ }^{17,18}$.

Treatment of OSAS by CPAP, despite improving important clinical parameters, does not always result in subjective benefit to the patient, who often does not tolerate the treatment itself, or the requirements and obstacles to live with a stigmatizing apparatus ${ }^{19}$. It should also be noted that, when thinking about a global treatment, patients with an AHI 30/hour but without symptoms of daytime sleepiness are poorly tolerant to and compliant with CPAP, leading to discontinuous and reduced utilization of this treatment, a fact suggesting that CPAP should not be indicated to these patients ${ }^{19}$.

The difficulty of treatment with CPAP, or subtreatment by this modality might create a contingent of unsatisfied patients and, even more important, of patients submitted to the consequences of OSAS and falsely protected by a potentially good, but restricted, therapy. The utilization of an IOM R by Yoshida ${ }^{14}$ in a clinical study on 256 patients demonstrated improved oxygen saturation, reduced duration of apneas, increased sleep efficiency, and a reduction in total microarousals. Compliance with the IOM R continued to be high ( $90 \%$ ) even after 2.5 years, clearly demonstrating that the mandibular repositioner offers some advantages over other therapies, in addition to its low cost, easy fabrication ${ }^{14}$, and the absence of side effects, with excellent improvement in the quality of life as shown in the present study.

Some authors still criticize the small number of studies analyzing the effects of OSAS on quality of life and of the response to CPAP treatment. However, studies have demonstrated that all quality of life aspects ranging from physical to emotional health and social interaction are notably compromised by OSAS and that CPAP therapy improves aspects related to vitality, social interaction and mental health ${ }^{20,21}$.

As stated above, the main problem of patients treated with CPAP might be related to the daily living with the equipment and its side effects, with a large number of patients showing up to 30 events per hour but with low daytime sleepiness indices benefitting from the advent of the IOMR R ${ }^{11,22}$. OSAS can by controlled by these appliances in many patients, who no longer require the obligatory use of CPAP but who use a more comfortable, less invasive device which is more versatile during daily life and has fewer psychological repercussions, especially in young patients who feel disturbed by the daily dependence on CPAP.

The results of the present study suggest that the IOMR effectively improved the quality of life of patients with mild to moderate OSAS. Based on the nature and aim of the treatments available for OSAS, comparative clinical studies between CPAP and IOM $R$ are required, whose outcome does not only focus on the apnea index but also on the quality of life of patients with OSAS.

\section{REFERENCES}

1. Cohn A. Pesquisa social em saúde. São Paulo: Cortez, 1992. 
2. Rosenthal TL, Bryant ES, Lemmi H. Gender differences dominate sleep disorder patients' body problem complaints. Arq Neuropsiquiatr 1994;52:471-475.

3. Hasan N, Fletcher EC. Upper airway resistance syndrome. J Ky Med Assoc 1998;96:261-263.

4. American Academy of Sleep Medicine Task Force. Sleep-related breathing disorders in adults: recommendations for syndrome definition and measurement techniques in clinical research. Sleep 1999;22:667-689.

5. Rechtschaffen A, Kales A. A manual of standardized terminology, techniques and scoring system for sleep stages of human subjects. Los Angeles: BIS/BRI, UCLA, 1968.

6. Reimao R, Gouveia MM, Pestana MCG, Lopes SR, Papaiz EG, Papaiz LF. Obstructive sleep apnea treatment with dental appliance. Arq Neuropsiquiatr 1994;52:560-565.

7. Reimao R, Lemmi H, Akiskal H, Cocke E. Acompanhamento polissonográfico das apnéias do sono após uvulopalatofaríngoplastia. Arq Neuropsiquiatr 1985;43:360-364.

8. Athen B. Intra-oral therapy of borderline sleep-related respiratory disorders with a modified protrusion-fixation of the mandible. Pneumologie 1999;53:88-91.

9. Bridgman SA, Dunn KM. Surgery for obstructive sleep apnoea. Cochrane Database Syst Rev 2000;CD001004.

10. Cohen R. Obstructive sleep apnea: oral appliance and severity of condition. Oral Surg Med Oral Pathol Oral Radiol Endod 1998;85:388-392.

11. Walker-Engstrom ML, Wilhelmsson B, Tegelberg A, Dimenas E, Ringqvist I. Quality of life assessment of treatment with dental appliance or UPPP in patients with mild to moderate obstructive sleep apnea: a prospective randomized 1-year follow-up study. J Sleep Res 2000;9:303-308.

12. Yang EH, Hla KM, McHorney CA, Havighurst T, Badr MS, Weber S. Sleep apnea and quality of life. Sleep 2000;23:535-541.

13. Rose EC, Barthlen GM, Staats R, Jonas IE. Therapeutic efficacy of an oral appliance in the treatment of obstructive sleep apnea: a 2-year follow-up. Am J Orthod Dentofacial Orthop 2002;121:273-279.

14. Yoshida K. Effects of a mandibular advancement device for the treatment of sleep apnea syndrome and snoring on respiratory function and sleep quality. Cranio 2000;18:98-105.

15. Flemons WW, Reimer MA. Development of a disease-specific healthrelated quality of life questionnaire for sleep apnea. Am J Respir Crit Care Med 1998;158:494-503.

16. Lacassi $Y$, Godbout C, Series F. Independent validation of the sleep apnoea quality of life index. Thorax 2002;57:483-488.

17. Flemons WW, Reimer MA. Measurement properties of the Calgary sleep apnea quality of life index. Am J Respir Crit Care Med 2002;165:159-164.

18. Heitman SJ, Flemons WW. Evidence-based medicine and sleep apnea. Respir Care 2001;46:1418-1432.

19. Barbe F, Mayoralas LR, Duran J, et al. Treatment with continuous positive airway pressure is not effective in patients with sleep apnea but no daytime sleepiness, a randomized, controlled trial. Ann Intern Med 2001;134:1065-1067.

20. D'Ambrosio C, Bowman T, Mohsenin V. Quality of life in patients with obstructive sleep apnea: effect of nasal continuous positive airway pressure - a prospective study. Chest 1999;115:123-129.

21. Pradela M, Sunseri M, Ferriere G. Effects of body position on sleep related disordered breathing in a patient with Steinert's disease. Arq Neuropsiquiatr 1993;51:529-531.
22. Randerath WJ, Heise M, Hinz R, Ruehle KH. An individually adjustable oral appliance vs continuous positive airway pressure in mild-to-moderate obstructive sleep apnea syndrome. Chest 2002;122:569-575. 